\begin{tabular}{|c|c|}
\hline 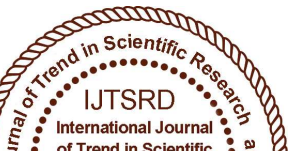 & $\begin{array}{l}\text { International Journal of Trend in Scientific } \\
\text { Research and Development (IJTSRD) }\end{array}$ \\
\hline 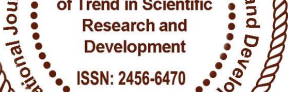 & International Open Access Journal \\
\hline 000 & ISSN No: 2456 - 6470 | www.ijtsrd.com | Volume - 2 | Issue - 3 \\
\hline
\end{tabular}

\title{
Concept of Smart Village and it's Impact on Rurbanization
}

\author{
Boda Ramesh \\ Geography Department, Osmania Univirsity, Hyderabad, India
}

\begin{abstract}
According to census 2011 data, $69 \%$ of rural population or 833 million people lived in rural areas, against $31 \%$ or 377.1 million people in urban people that's why very huge importance to smart village in India. India is a country dominated by villages. So that developing India it must to develop villages first, because of lack of communication problem in villages they do not have central communication system. Smart Village is a concept adopted by national, state and local governments of India, as an initiative focused on holistic rural development, derived from Mahatma Gandhi's vision of Adarsh Gram(Ideal Village) and Swaraj (Self Reliance) Prime Minister Narendra Modi launched Samsad Adarsh Gram Yojana (SAGY) on 11 October 2014, Gandhi's birthday, in addition to Smart Cities" and "Digital India", as a development programme for India. The Parliamentarian's Model Village Scheme main goal is for each Member of Parliament and Minister to adopt a rural village and develop it into a model by 2019 . The vision of SAGY is an integrated village development plan, encompassing Personal, Human, Social, and Economic dimensions.
\end{abstract}

Keywords: Holistic, Adarsh Gram, Swaraj, Encompassing, Smart city, Digital India

\section{INTRODUCTION}

Smart Village India gets its foundation from Mahatma Gandhi's vision of Adarsh Gram (model village) and Gram Swaraj (Village self-rule/independence). Gandhi in two texts, Hind Swaraj and Gram (Village) Swaraj, promotes the concept of integrated rural development to impact majority of the population, as the primary initiative after India Independence in 1947. The Eco Needs Foundation has initiated the concept of "Smart Village". Under this project the

Foundation is adopting villages and putting efforts for sustainable development by providing basic amenities like,
- Sanitation,
- Safe drinking water
- Internal road
- Tree plantation
- Water conservation.

Under the concept of Smart Village, the Foundation has adopted Village Dhanora, Tehsil.Bari, District Dholpur, one of the remote small village of Rajasthan to develop it as India's First Smart Village. The village is situated $30 \mathrm{~km}$ away from Dholpur district head quarter and $248 \mathrm{Km}$ from Jaipur. The population of the village is nearly about 2000 having no sanitation facility, potable water facility. Which are adversely causing the health of the villagers. The internal roads are also not there and it causes great hardship to the people especially in rainy season. Owing to unawareness and non-availability of sanitation facility and toilets the people of the village use to go open for defecation. There are other problems also which villagers were facing such as Fluoride concentration in drinking water, No water conservation System, Encroachment on the roads, Electrical power fluctuation No outcome base education, Unemployment and poverty.

\section{OBJECTIVE}

The Foundation is also working for inculcating moral values in the society and for improving the standard of living of the villagers. In the concept of "Smart Village" the development of the village shall be based on the five paths 
- Retrofitting

- Redevelopment

- Green fields

- E-Pan

- Livelihood

\section{METHODOLOGY}

Smart village concept is led foundation to Rurbanization in India. In smart villages some features are

1. Water conservation

2. Health

3. Education

4. Energy

5. Good transport system.

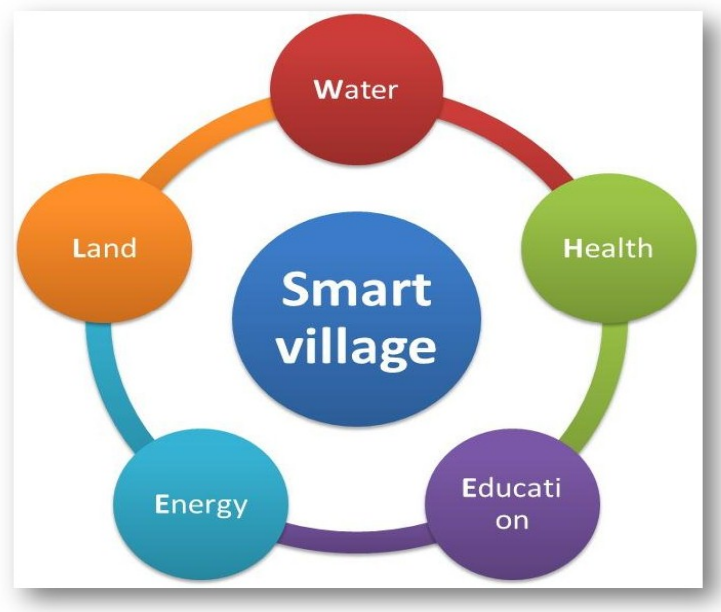

\section{REQUIREMENT OF SMART VILLAGE}

Energy conservation.

$>$ Water conservation

$>$ Good health facility

$>$ Good transport system

$>$ Good education facility

$>$ Grievance redresser.

> Strengthening CBOs.

$>$ Functional bank account.

$>$ Facilities regarding to the agriculture

$>$ Latest\& affordable medical facility
$>$ E-governance.

$>$ Use of modern technologies for improvement of locality.

Improvement on women empowerment.

Smart security.

$>$ Efficient public transportation system.

$>$ Improving sanitation conditions

$>$ Solid and liquid waste management.

$>$ Rain harvesting /Rain water drainage system.

$>$ Safe drinking water facilities.

Use of renewable energy.

\section{CONCLUSION}

Villages are being ignorant during the industrialization period in India. $69 \%$ of India lives in villages, if it is ignored, then it will hamper the economic growth of the country. To boost villages socially, economically Smart village concept has been introduced as envisaged by the great Mahatma Gandhi. Villages are backbone of our country's economic growth as most of the

primary sector activities occur in villages. To explore new opportunities and dimensions for the rural population in other sectors will definitely boost the country's growth. In that path Smart village is an initiation through the concept of Rurbanization.

\section{REFERENCES}

1) Sinha, Shri Amarjeet. "Secretary, Department of Rural Development" (model-village) Managed by Ministry of Rural Development, Government of India. Retrieved 29 November 2016.

2) Garg, B.S.Raut, A.V. (2015). "Adarsh Gram: A Gandhian Dream of Gram Swaraj"

3) Gandhi, Mahatma (2010). Hind swaraj (Centenary ed.). Delhi: Rajpal \& Sons

4) Gandhi, Mahatma (1962). Village Swaraj. University of California: Navajivan Publishing House. Contents Background Values Implementation by states.

5) Amitabh, Utkarsh (3 October 2016). "Young India Fellow, Young India Fellowship, Ashoka University". 
International Journal of Trend in Scientific Research and Development (IJTSRD) ISSN: 2456-6470

6) Tomar, Shri Narendra Singh. "Minister of Rural Development, Panchayat Raj, Drinking Water and Sanitation",Ministry of Rural Development, Government of India. Retrieved 29 November 2016.

7) Kaushik, Preetam (25 November 2014). "Smart Villages: Lending A Rural Flavour To Modi's Growth Agenda.
8) "Central Government Departments and the Programme coordinated by Ministry of Electronics \& Information Technology".

9) Tewari,Ankur(2014)."Experts envision smart villages in India"

10) Sinha, Shri Amarjeet."Holistic Development Through:vities-in-an-adarsh-gram".

11) Internet information. 